\title{
MENGUATKAN UKHUWAH MELALUI BERBAGI ANTAR SESAMA YANG TERDAMPAK COVID-19
}

\author{
Isep Amas Priatna, Yhonanda Harsono, Udin Saprudin, Bucharie E Setiaputra, \\ Lucia Maduningtias \\ Universitas Pamulang \\ Email: dosen01629@unpam.ac.id
}

\begin{abstract}
In this PKM, by taking the object of service, namely residents affected by Covid 19, generally laborers and traders who are residents of RT $001 R W$ 06 Caringin Legok Tangerang. Community service partners in this PKM Management/BPH RT 001/06. The problem that was taken came from the number of residents of RT 001 RW 06 Caringin Legok Tangerang who were affected by their household income as a result of Covid 19. The assistance program provided was in accordance with the results of observations and surveys, namely the provision of basic food assistance which was the result of donations collected from donors, provision of counseling to affected residents about business opportunities that could be a source of new livelihoods during the Covid 19 pandemic. In implementing this PKM, the number of aid packages given was 35 packages while the number of participants in counseling was 20 people. In the future, $R T$ administrators as community service partners are advised to have cash proceeds from regular residents' fees that are ready to be given when conditions are critical for residents affected by Covid 19 besides designing a joint business model that is able to embrace SMEs so that their businesses can grow and future service is expected. provide more applicable training.
\end{abstract}

Keywords: Covid 19, Counseling and Donations

\begin{abstract}
Abstrak
Pada PKM ini dengan mengambil objek pengabdian yaitu warga yang terdampak covid 19 yang umumnya para pekerja buruh dan pedagang yang meruapakan warga dari RT 001 RW 06 Caringin Legok Tangerang. Mitra pengabdian pada PKM ini Pengurus/BPH RT 001/06. Masalah yang diambil berasal dari banyaknya warga RT 001 RW 06 Caringin Legok Tangerang yang terdampak pendapatan rumah tangganya akibat dari covid 19. Program bantuan yang diberikan sesuai dari hasil pengamatan dan survey yakni pemberian bantuan sembako yang merupakan hasil dari donasi yang dikumpulkan dari donator, pemberian penyuluhan kepada warga yang terdampak tentang peluang usaha yang bisa menjadi sumber matapencaharian baru di saat pademi covid 19. Dalam pelaksanaan PKM ini, jumlah paket bantuan yang diberikan sejumlah 35 Paket sedangkan jumlah peserta dalam penyuluhan sebanyak 20 orang. Kedepan, pengurus RT sebagai mitra pengabdian disarankan agar memiliki kas hasil dari iuran
\end{abstract}


rutin warga yang siap untuk diberikan disaat kondisi kritis bagi warga yang terdampak pademi covid 19 selain itu merancang model usaha bersama yang mampu merangkul para UKM agar usaha mereka semakin berkembang dan pengabdian kedepan diharapkan memberikan pelatihan yang lebih aplikatif.

Kata Kunci : Covid 19, Penyuluhan dan Donasi

\section{A. PENDAHULUAN}

Covid-19 merupakan penyakit menular yang disebabkan oleh virus bernama SARSCOV-2, atau seringkali disebut Virus Corona. Virus Corona sendiri merupakan keluarga virus yang sangat besar. Ada yang menginveksi hewan, seperti kucing dan anjing, namun ada pula jenis Virus Corona yang menular ke manusia, seperti yang terjadi pada Covid-19. Covid-19 merupakan penyakit baru, jadi manusia belum punya kekebalan tubuh terhadap VIrus SARS-Cov-2. Vaksin dan obatnya belum ditemukan. saat ini peneliti dipenjuru dunia masih berlomba-lomba untuk mencari vaksin dan obatnya.

Kurangnya sosialisasi dan tanggapnya pemerintah terhadap virus ini menyebabkan hampir diseluruh dunia terinfeksi virus Covid-19. Selain itu, masyarakat kurang sadar akan pentingnya menjaga kesehatan dan kebersihan. Kurangnya sosialisasi pedoman, pencegahan dan pengendalian Covid-19 kepada masyarakat, sehingga banyak yang tidak mengetahui bahwa dirinya Orang Dalam Pemantauan (ODP), Pasien Dalam Pengawasan (PDP) dan Suspek dan mereka merasa sehat dan masih keluar kota dan keluar negeri, tanpa disadari sudah membawa virus covid-19. Masih banyak masyarakat yang tidak mentaati peraturan pemerintah untuk dirumah saja menjadi bagian penyebab kenaikan penularan yang terjadi hampir di 200 Negara.

Hal tersebut menyebabkan kenaikan kasus yang terinfeksi Covid-19 hampir 200 Negara didunia. Dari 193 negara YANG TERINFEKSI Covid-19 pertanggal 14 April 2020 sebanyak 1.920.057 orang, sembuh 443.732 orang dan meninggal 119.403. Data yang diperoleh pertanggal 14 April 2020 jumlah yang terinfekdi di Indonesia terus meningkat dengan total 4.839 kasus, dirawat sebanyak 3.954, meninggal 459 dan sembuh sebanyak 426 orang. dari jumlah tersebut Provinsi DKI Jakarta paling tinggi yang terinfeksi sebanyak 2.335 orang. Hal ini menyebabkan banyak Pemimpin Pemerintah Daerah yang melakukan lockdown didaerahnya masing-masing untuk mengurangi penularan virus tersebut. Oleh karena itu, Pemerintah Daerah mengajukan Pembatasan Sosial Berskala Besar (PSBB) yang diajukan kepda Menteri Kesehatan diatur dalam Undang-Undang No.6 Tahun 2018 tentang Karantina Kesehatan dan sesuai dengan keputusan Presiden Republik Indonesia Nomor 11 Tahun 2020 tentang Penetapan Kedaruratan Kesehatan Masyarakat Corona Virus Desease 2019 (Covid19).

Penyebaran Cobid-19 yang bersifat luar biasa dengan ditandai jumlah kasus atau jumlah kematian telah meningkat dan meluas lintas wilayah dan lintas Negara dan berdampak pada aspek politik, ekonomi, sosisal, budaya, pertahanan dan keamanan, serta kesejahteraan masyarakat di Indonesia, maka Presiden mengeluarkan Peraturan Pemerintah Republik Indonesia Nomor 21 Tahun 2020, tentang Pembatasan Sosial Berskala Besar Dalam Rangka Percepatan Penanganan Corona Virus Disease 2019 (Covid-19).

Merujuk dari Undang-Undang dan Peraturan Pemerintah tersebut, beberapa Pemimpin Daerah yang meningkat penyebaran Covid-19 mengajukan PSBB ke Kementerian Kesehatan, Pada tanggal 7 April 2020 Kementrian Kesehatan mengeluarkan Surat Keputusan Menteri Kesehatan Republik Indonesia Nomor HK.01/07/MENKES/239/2020 tentang penetapan 
Pembatasan Sosial Berskala Besar di wilayah provinsi DKI Jakarta dalam rangka percepatan penanganan Covid-19. Setelah dikeluarkan SK Menkes tersebut Gubernur DKI Jakarta mulai menerapkan PSBB diwilayah DKI Jakarta dari tanggal 10 April 2020 sampai tanggal 23 April 2020. Apabila dalam waktu 14 hari tidak ada penurunan maka dapat diperpanjang lagi selama 14 hari berikutnya.

Hal tersebut diikuti beberapa provinsi lainnya seperti Banten dan Jawa Barat. Pemerintah provinsi Banten menegluarkan peraturan Gubernur tentang pedoman Pembatsan Sosial Berskala Besar (PSBB) yang berlaku untuk Tangerang kota,Tangsel, Kab Tangerang atau Serang dimulai dari 15 April 2020 dan disosialisasikan dimulai tanggal 13-14 April 2020. Peraturan Gubernur tentang pedoman pelaksanaan Pembatasan Sosial Berskala Besar (PSBB) dalam penanganan Covid-19 di Banten, isinya mengatur Pembatasan disektor pendidikan, tempat kerja, fasilitas umum dan ibadah, kegiatan budaya sampai modal transportasi, dan disebut paling akhir ini, termasuk penggunaan kendaraan pribadi, hingga protap angkutan roda dua berbasis online. Peraturan Gubernur Banten Nomor 27 Tahun 2020 tentang: Pedoman Pembatasan Sosial Berskala Besar dalam penanganan Covid 19 di daerah Kabupaten Tangerang, daerah kota Tangerang, daerah kota Tangerang Selatan, daerah Kabupaten Serang, daerah Kota Serang dan Cilegon.

Dampak covid 19 yang terjadi di Provinsi Banten sangat berpengaruh kepada seluruh lapisan masyarakat yang pendapatannya menengah kebawah, salah satunya terjadi di Komplek Perumahan Griya Permai Caringin Legok Tangerang. Permasalahan yang muncul yaitu adanya pemutusan mata rantai penghidupan berupa tidak bisa bekerja atau mencari mata pencaharian akibat dari PHK maupun terhentinya aktivitas berdagang. Dengan adanya Pandemi Covid-19 mereka tidak mendapatkan penghasilan dikarenakan semuanya tidak diizinkan untuk keluar rumah. Oleh karena itu Dosen Universitas Pamulang khususnya Program Studi Manajemen bekerjasama dengan Kepengurusan RT 001/06 sebagai mitra pengabdian untuk merancang program bantuan untuk masyarakat yang terdampak covid 19 . Program yang dijalankan tidak saja dalam bentuk bantuan langsung berupa paket sembako namun selain itu memberikan penyuluhan tentang peluang usaha yang memberikan peluang penghasilan di saat kondisi pademi covid 19

\section{B. METODE PELAKSANAAN KEGIATAN}

Kerangka pemecahan masalah yang dilakukan dalam pengabdian pada masyarakat di RT di RT 001/06 Perumahan Griya Permai dimulai dengan melakukan analisis situasi meliputi kondisi riil yang terjadi di obyek pengabdian yang bersumber dari Pengurus RT 001 RW 06 selanjutnya menelaah dan menetapkan pendekatan pengabdian pada masyarakat sesuai kebutuhan. Hal ini dilakukan agar program pengabdian memiliki daya rubah yang besar sekaligus membantu meringankan beban masyarakat yang terdampak covid 19. Pendekatan terbagi menjadi dua yang pertama menitikberatkan kepada bantuan langsung berbentuk paket sembako dan yang kedua adalah berbentuk penyuluhan yang lebih menitikberatkan kepada pemberian motivasi dalam memahami peluang usaha di masa pandemic covid 19. Dari dua pendekatan ini diharapkan ada pengaruh terhadap ppenguatan ekonomi masyarakat di RT di RT 001/06 Perumahan Griya Permai

\section{HASIL DAN PEMBAHASAN}

\section{Letak Geografi Lokasi Pengabdian}

Pelaksanaan kegiatan pengabdian masyarakat bertempat di Perumahan Griya Permai RT 001/06 Caringin, Legok - Tangerang. Griya Permai adalah sebuah Perumahan di desa Caringin, Kecamatan Legok Kabupaten Tangerang dengan luas komplek 2 Ha. Perumahan 
Griya Permai berjarak kurang lebih 3 kilometer sebelah barat dari kantor Desa Caringin. Perumahan Griya Permai dikelola RW06 terdiri dari 7 RT Yaitu : RT 001, RT 002, RT 003, RT 004, RT 005, RT 006 dan RT 007.

Jumlah penduduk warga Perumahan Griya Permai tahun 2020 mencapai 2.400 jiwa. yang terdiri dari 1.213 jiwa penduduk laki-laki dan 1.187 jiwa penduduk perempuan. Sex ratio penduduk warga perumahan Griya Permai adalah 104 yang berarti tiap 100 penduduk perempuan terdapat 104 penduduk laki-laki. Penduduk warga di Perumahan Griya Permai mayoritas menganut agama Islam yaitu sebanyak 2.230 jiwa sisanya yaitu Kristen, Katholik,dan Budha. Jumlah rumah tangga yang ada di Perumahan Griya Permai Desa Caringin Legok adalah $800 \mathrm{KK}$.

\section{Tahap Persiapan Pelaksanaan Kegiatan}

Kami melakukan survey kepada kepengurusan RT dan BPH untuk memastikan kondisi warga yang terdampak covid 19 khusunya data pedagang dan buruh yang ada komplek perumahan Griya Permai khususnya RT001/06. Data ini diperlukan untuk menyusun daftar bantuan yang hendak diberikan sekaligus menjadi pertimbangan didalam keikutsertaan dalam kegiatan penyuluhan. Selain melakukan pendataan penerima bantuan, tim juga berupaya mengundang para donator untuk dapat memberikan bantuan kepada masyarakat yang terdampak covid 19 dengan cara membuka rekening program bantuan.

Setelah melakuakn survey maka tahap selanjutnya menentukan lokasi pelaksanaan dan penentuan sasaran yang benar-benar membutuhkan bantuan. Penetapan lokasi ini berguna agar penyelenggaraan kegiatan bisa memudahkan masyarakat penerima bantuan untuk datang pada lokasi kegiatan. Lokasi kegiatan lebih banyak merupakan usulan dari pengurus RT karena mereka yang telah memahami kondisi lokasi.

\section{Tahap Pelaksanaan Kegiatan}

Pada tahap ini kami memberikan donasi kepada kepengurusan RT001/06 untuk didistribusikan kepada para pekerja buruh dan pedagang yang terkena dampak Covid-19 dan bantuan donasi tersebut selanjutnya akan dibelikan sembako yang mereka butuhkan. Melalui media sosial, dana yang terkumpul kami berikan dan serahkan melalui transfer ke rekening sekertariat RT dan langsung dibelikan paket sembako oleh kepengurusan RT dan BPH untuk segera didistribusikan kepada yang membutuhkan. Jumlah paket yang disalurkan dari hasil pengumpulan donasi sebanyak 35 Paket yang berisi semabako yang sesuai dengan hasil pendataan warga sebagai obyek pengabdian. Penyerahan bantuan paket secara resmi diberikan kepada Pengurus RT 001 RW 06 sebagai mitra pengabdian dosen prodi manajemen Universitas Pamulang.

Selain dari pemberian paket sembako sebagi bagian stimulus bagi kehidupan masyarakat yang terdampak, untuk menunjang kegiatan dalam upaya membantu masyarakat yang terdampak covid 19 , maka dilakukan penyuluhan tentang peluang usaha di masa pademi 19. Penyuluhan ini diawali dengan tema tentang dampak covid 19 kepada perekonomian secara luas selanjutnya dilanjutkan dengan bagaimana kondisi masyarakat selama pademi dan terakhir peluang usaha yang bisa diciptakan pada saat kondisi pademi. Masyarakat yang hadir sangat antusias, terlihat dari mengikuti kegiatan secara full dan banyak pertanyaan terkait dengan peluang-peluang usaha yang ingin mereka jalani. Tujuan dari kegiatan penyuluhan ini adalah memberikan kesadaran kepada masyarakat yang terdampak akan kondisi yang sebenarnya terjadi dan bukan dialami oleh warga RT 01/06 selain itu memberikan pemahaman yang mendalam bahwa walau dengan kondisi pademi tetapi peluang usaha masih bisa muncul dan tumbuh berkembang di saat masa pademi ini. 


\section{KESIMPULAN DAN SARAN}

\section{Kesimpulan}

Bagi warga dengan kelompok ekonomi yang rendah, pademi covid 19 mempengaruhi kepada pendapatan ekonomi keluarga yang disebabkan sumber pendapatan yang selama mereka nikmati ikut terpengaruh. Demi keberlanjutan hidup maka perlu dilakukan bantuan secara langsung kepada mereka yang terdampak yang berbentuk paket sembako selain itu juga perlu dilakukan pemahaman tentang peluang usaha dimasa pademi 19. Hal ini sangat penting karena dengan bantuan sembako atau pangan setidaknya memberikan daya tahan tambahan sebelum memiliki sumber pendapatan baru. Namun demikian upaya-upaya pemberian pembahaman tentang peluang usaha baru juga perlu dilakukan agar wawasan mereka berkembang sehingga tidak memutus harapan kehidupan.

\section{Saran}

Bagi pengurus RT sebagai mitra pengabdian disarankan agar memiliki kas hasil dari iuran rutin warga yang siap untuk diberikan disaat kondisi kritis bagi warga yang terdampak pademi covid 19 selain itu merancang model usaha bersama yang mampu merangkul para UKM agar usaha mereka semakin berkembang. Bagi dosen-dosen yang ingin terjun dalam pengabdian disarankan untuk memberikan pengabdian yang lebih aplikasi dalam bantuan peluang usaha seperti pemberian pelatihan praktek usaha yang menjanjikan di masa pademi

\section{Ucapan Terima Kasih}

Rasa syukur dan suka cita kamu haturkan kepada segenap pihak yang telah mensukseskan kegiatan PKM dengan judul "Menguatkan Ukhuwah Melalui Berbagi Antar Sesama Yang Terdampak Covid 19" kepada:

1. Rektor Dr. H. Dayat Hidayat, M.M, Rektor Universitas Pamulang Tangerang Selatan Banten.

2. Dr. Ali Maddinsyah, S.E., M.M., selaku Ketua LPPM Universitas Pamulang Tangerang Selatan - Banten.

3. Dr. Kasmad, S.E., M.,M., selaku Ketua Program Studi Manajemen Universitas Pamulang Tangerang Selatan - Banten.

4. Dr. Udin Ahidin, S.E., M.M., C.M.A, Selaku Wakil Program Studi Manajemen Universitas Pamulang Tangerang Selatan - Banten.

5. Drs. Waluyo Jati, M.M., Selaku Sekretaris Program Studi Manajemen Universitas Pamulang Tangerang Selatan - Banten.

6. Soyanudin, selaku Ketua RT 001/06 Caringin Legok Tangerang.

7. Mahasiswa Universitas Pamulang yang juga ikut berkontribusi terhadap kelancaran kegiatan PKM.

\section{DAFTAR PUSTAKA}

Pasal 4 ayat (1) Undang-Undang Dasar Negara Republik Indonesia Tahun 1945;

UU No. 6 Tahun 2018 tentang Karantina Kesehatan (Lembaran Negara Republik Indonesia Tahun 2018 Nomor 128, Tambahan Lembaran Negara Republik Indonesia Nomor 6236); 
Peraturan Pemerintah Republik Indonesia Nomor 21 tahun 2020 Tentang Pembatasan Sosial

Berskala Besar Dalam Rangka Percepatan Penanganan Corona Virus Disease 2019 (Covid-19);

Keputusan Presiden Republik IndonesiaNomor 11 tahun 2020 Tentang Penetapan Kedaruratan Kesehatan Masyarakat Corona Virus Disease 2019 (Covid- 19);

Surat Keputusan Menteri Kesehatan Nomor HK.01.07 Menkes/239/2020, tentang Penetapan Pembatasan Sosial Berskala Besar di Wilayah Provinsi DKI Jakarta Dalam Rangka Percepatan Penanganan Corona Virus Disease 2019 (COVID 19);

Surat Edaran Nomor 2 Tahun 2020 tentang Pencegahan dan Penanganan COVID-19 di Lingkungan Kemendikbud;

Surat Edaran Nomor 3 Tahun 2020 tentang Pencegahan COVID-19 pada Satuan Pendidikan;

Peraturan Gubernur Nomor 27 Tahun 2020 tentang Pedoman PSBB 